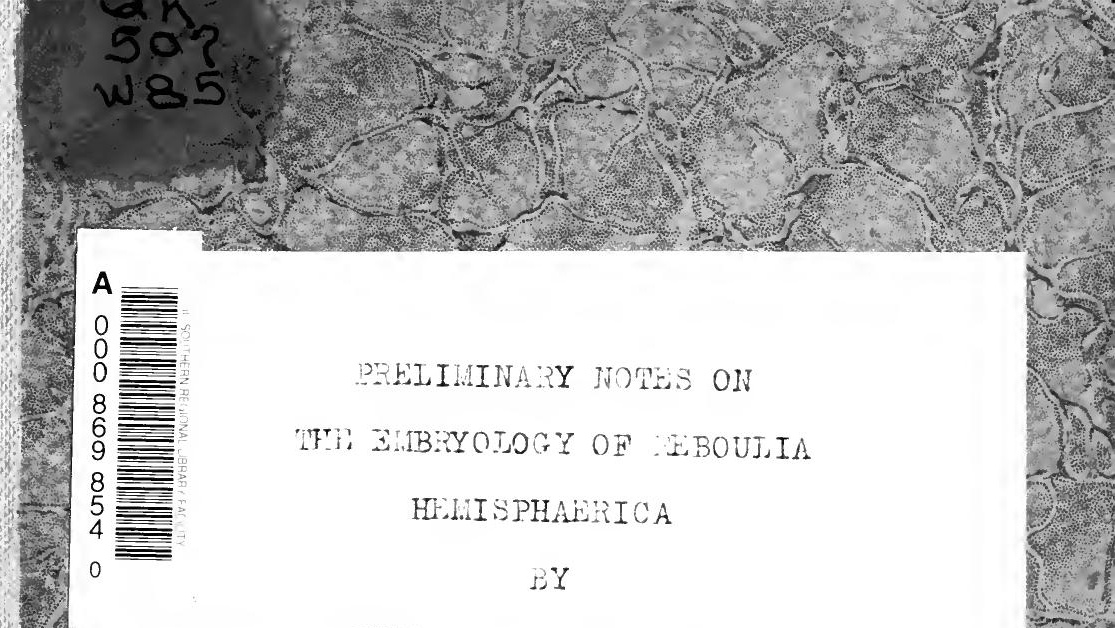

WIIIIAII I. WOOJBUEN

$-4$

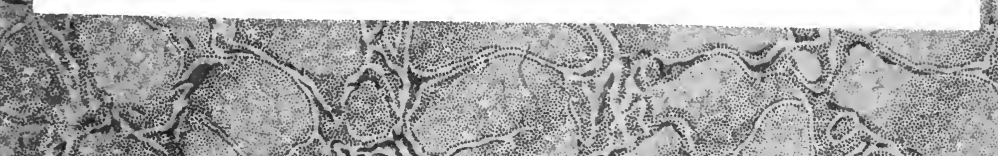

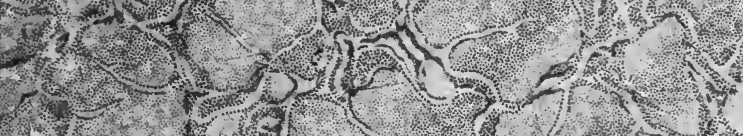

(2)

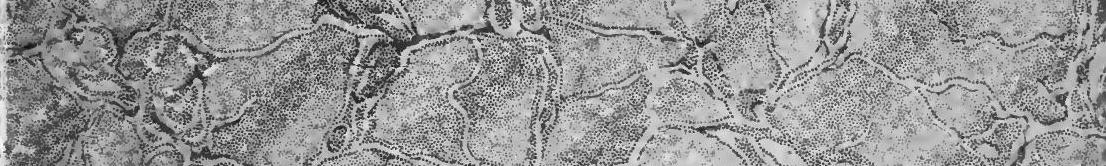

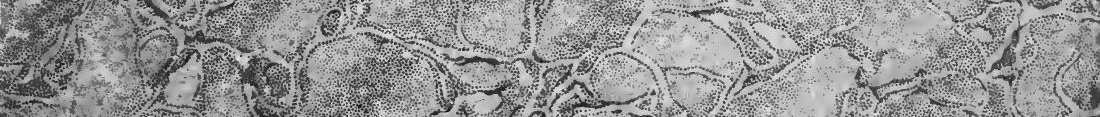

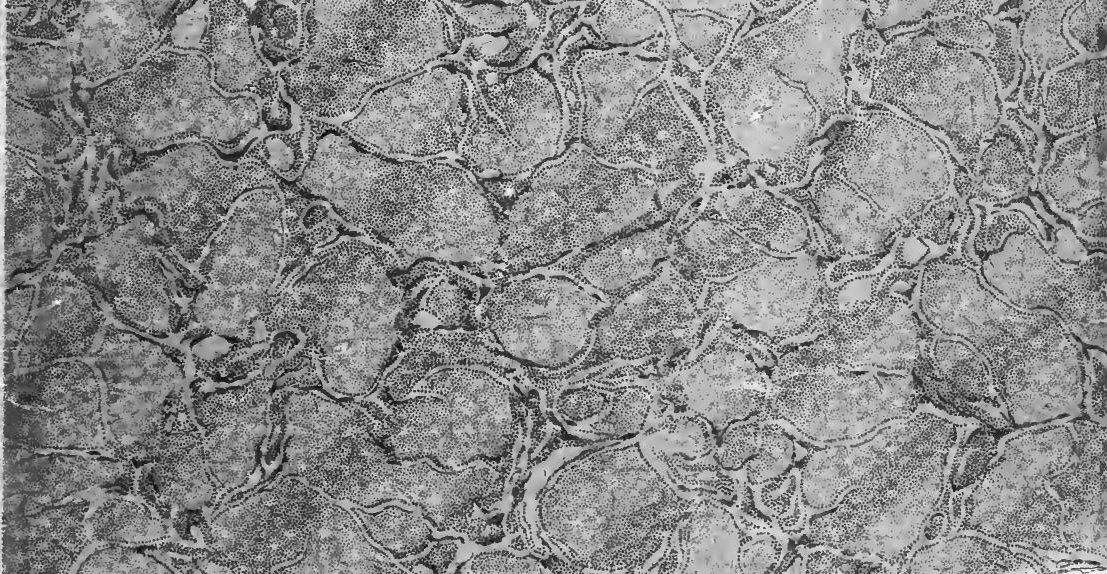




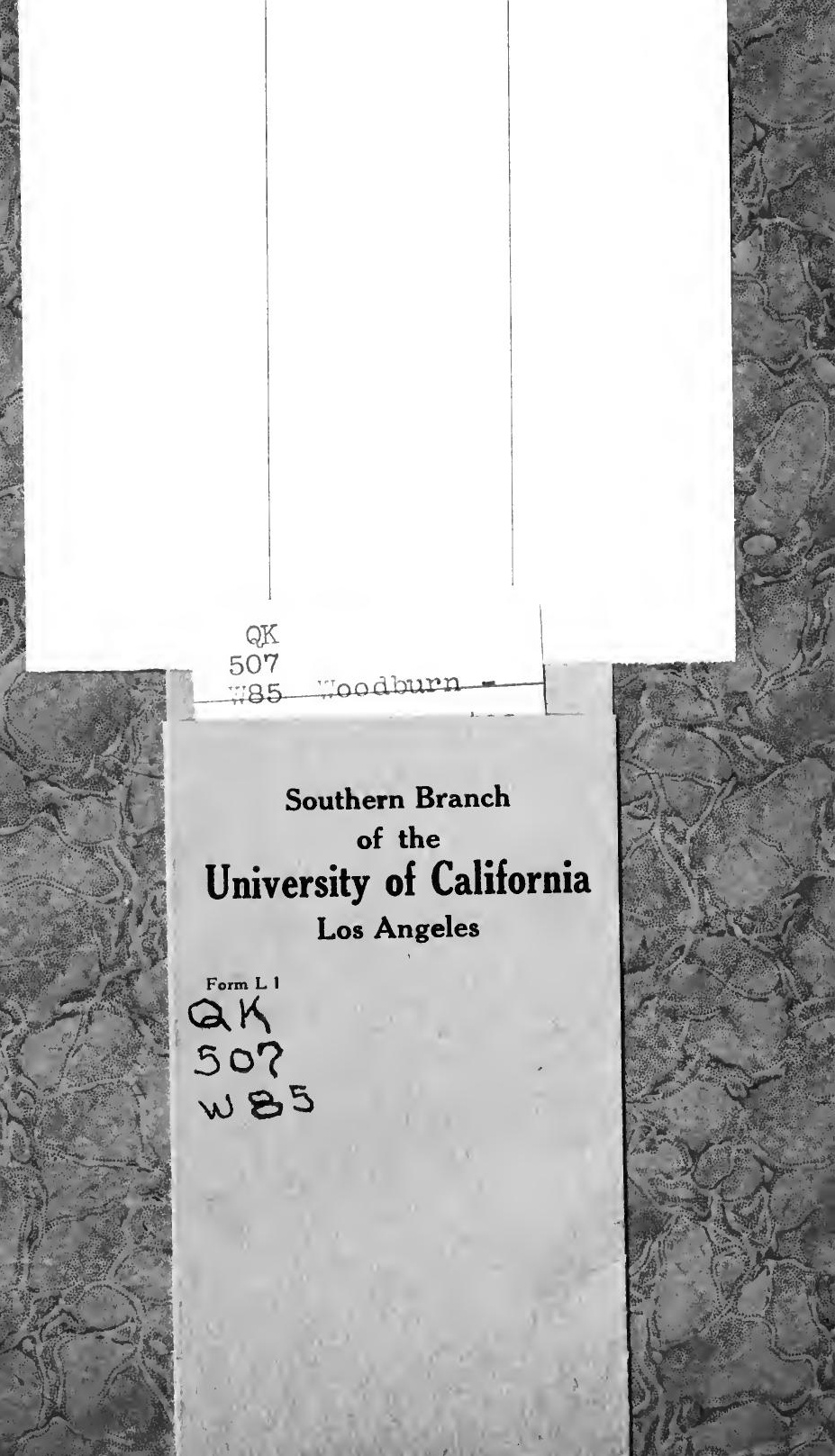




\title{
PRELIMINARY NOTES ON THE EMBRYOLOGY OF REBOULIA HEMISPHAERICA
}

\author{
WILLIAM L. WOODBURN
}

NEW YORK

1919 


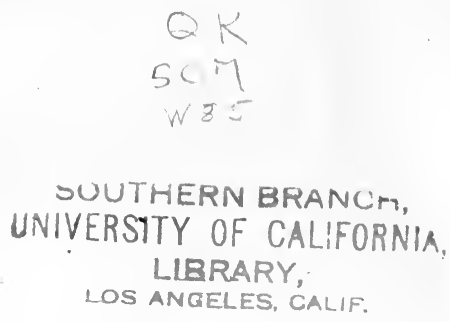

Preliminary notes on the embryology of Reboulia hemisphaerica

William L. WOODBURN

(WITH PLATE I9)

The object of this paper is to present a part of a more extended study on the embryology and cytology of Reboulia hemisphaerica (L.) Raddi. Only certain stages in the process of fertilization and in the early development of the embryo sporophyte will be considered at this time. The description of various other stages in the life history together with a summary of the previous literature on Reboulia will be left for a subsequent report.

\section{Fertilization}

The male gamete in the bryophytes may undergo two series of marked morphological changes. The first series includes the steps leading from the non-motile condition of the androcyte (the cell which directly becomes transformed into the mature sperm) through the formation of the actively motile free-swimming sperm. The second series includes the reverse steps and occurs in those cases where a sperm reaches an egg. In this second case the motile sperm becomes again non-motile with a resting nucleus similar to that of the androcyte or androcyte mother-cell. Details of the main stages in the first series have been carefully described for numerous liverworts and mosses. The processes accomplished in the second series, after the sperm reaches the egg, are not so well known. However, soon after 461 


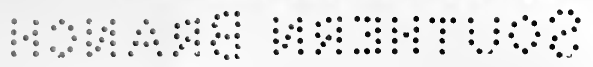

462 WOODBURY : EMBRYology of REBOULIA HEMISPHERICA

reaching the egg the sperm nucleus is found to have the form and structure of a nucleus in the resting stage (FIG. r). Quite similar conditions have been reported by Black (I) and Garber (3) for Riccia and by K. Meyer (4) for Corsinia. The form and structure of the egg and sperm nuclei at this stage are to a certain extent similar (FIG. I). The egg nucleus is larger and shows a coarser and more open disposition of the chromatin. An unstained area surrounds the nucleolus. A smaller nucleolus is present in the sperm nucleus. The latter as a whole stains somewhat more heavily than does the nucleus of the egg.

The accompanying figures are drawn as nearly as possible in that position which is occupied in nature. For instance, the necks of the archegonia at this stage of development project obliquely downward or toward the substratum. Consequently it will be seen that, in FIG. I, the sperm nucleus lies in contact with that side of the egg nucleus which is toward the neck of the archegonium. The membrane of the egg nucleus is somewhat infolded along the surface of contact.

Compared with corresponding stages in the life history of gymnosperms and angiosperms we know very little concerning the details of nuclear behavior in this and further stages of fertilization.

\section{EARLY DIVISIONS OF THE EMBRYO}

The first division wall of the zygote is laid down transversely. FIG. 2 represents the telophase of this first division, with the cell plate in the process of formation. The spindle lies parallel with the longitudinal axis of the venter of the archegonium; consequently a transverse basal wall results (FIGs. 2 and 3). In FIG. 3 the nuclei are in the prophase of subsequent division; " a" represents the hypobasal cell or that one next to the base of the archegonium, and $b$, the epibasal cell or that one next to the neck of the archegonium. The second division is transverse and occurs in the epibasal cell (compare FIGs. 3, 4, 5 and 6). The epibasal cell (FrG. 3, "b"), with the chromosomes clearly differentiated, is in a more advanced stage of prophase than the hypobasal cell. There is also evidence of centrosomes or centrosomelike structures connected with the nucleus. Fig. 4 represents the second division completed. Later stages (compare FIGS. 
$3,4,5,6$ and II) indicate that from the hypobasal cell is developed the foot and from the epibasal cell the stalk and sporangium of the mature sporophyte.

A third division follows in either the middle or apical cell of the tier of three (FIG. 4) which results from the first and second divisions. Compare Fig. 5, which shows a tier or series of four cells, with FIG. 4. Then follows (FIG. 6) a division in the basal or foot cell at right angles to the first three division walls. The foot at this stage has become quite dense in protoplasmic contents.

The order of divisions just described seems to represent the usual conditions. Compare, however, Figs. 2-6 with Figs. 7-10. In each section represented by FIGS. 7 and 9 there is a triangularshaped apical cell, while in FIGs. 8 and ro both apical and basal cells of triangular shape are present. FIG. I I represents a slightly different condition, in which the foot has become divided into an irregular group of cells.

In no case do we find the same sequence of early divisions as described by Cavers (2). In speaking of the early divisions of the sporophyte of Reboulia, he says, "The transverse basal wall is followed by two sets of nearly equal vertical walls which intersect each other at right angles, so that the embryo shows a regular octant stage."

\section{Summary.}

The egg and sperm nuclei are both in a resting condition in the earliest stages of fusion.

Among the Bryophytes little is known concerning the details of nuclear behavior during the stages of fertilization.

The earliest divisions of the zygote are transverse. A longitudinal series or tier of four cells may be formed.

Occasionally, however, both apical and foot cells of triangular outline may be formed, or the basal cell may divide in to an irregular group which constitutes the foot.

Of the first two cells formed, the hypobasal cell evidently produces the foot, and the epibasal cell the stalk and sporangium of the mature sporophyte.

Northwestern University,

Evanston, Illinois 


\section{LITERATURE CITED}

I. Black, Caroline A. The morphology of Riccia Frostii Aust. Ann. Bot. 27: 51 1-532. pl. 37, 38. 1912.

2. Cavers, F. Contributions to the biology of the Hepaticae. Part I.-Targionia, Reboulia, Preissia, Monoclea. Leeds and London. March, I904.

3. Garber, J. F. The life history of Ricciocarpus natans. Bot. Gaz. 37: 16I-177. pl. g, Io +f. I-4. 1904 .

4. Meyer, K. Untersuchungen über den Sporophyt der Lebermoose. Entwickelungsgeschichte des Sporogon der Corsinia marchantioides. Bull. Soc. Imp. Nat. Moscou I9II: 263-286. pl. II +f. I-22. I9I2.

\section{Explanation of plate 19}

The figures were drawn by Miss Mary C. Blair.

FIG. I. Early stage of fusion of the egg and sperm nuclei, $X$ I 775 .

FIG. 2. Telophase of first division of zygote, $\times 565$.

Fig. 3. First division of zygote completed; hypobasal cell "a," and epibasal cell " $b$ " in prophase of subsequent division, $\times 735$.

FIG. 4. Division of epibasal cell completed, showing tier of three cells, $\times 565$.

FIG. 5. Young embryo consisting of tier of four cells, $\times 565$.

FIG. 6. Hypobasal cell divided longitudinally; cell next above in process of longitudinal division, $\times 565$.

FIG. 7. Young embryo with wedge-shaped apical cell, $\times 735$.

FIG. 8. Young embryo with both basal and apical cells triangular in shape, $\times 735$.

FIG. 9. Embryo, older than in any of the preceding figures, with wedge-shaped apical cell $\times 565$.

FIG. Io. Slightly more advanced embryo than in FIG. 9, showing both apical and basal cells triangular in outline, $\times 565$.

FIG. II. Embryo showing early differentiation of foot " $a$," seta " $b$," and capsule "c," $\times 565$.

\section{$6558 \%$}



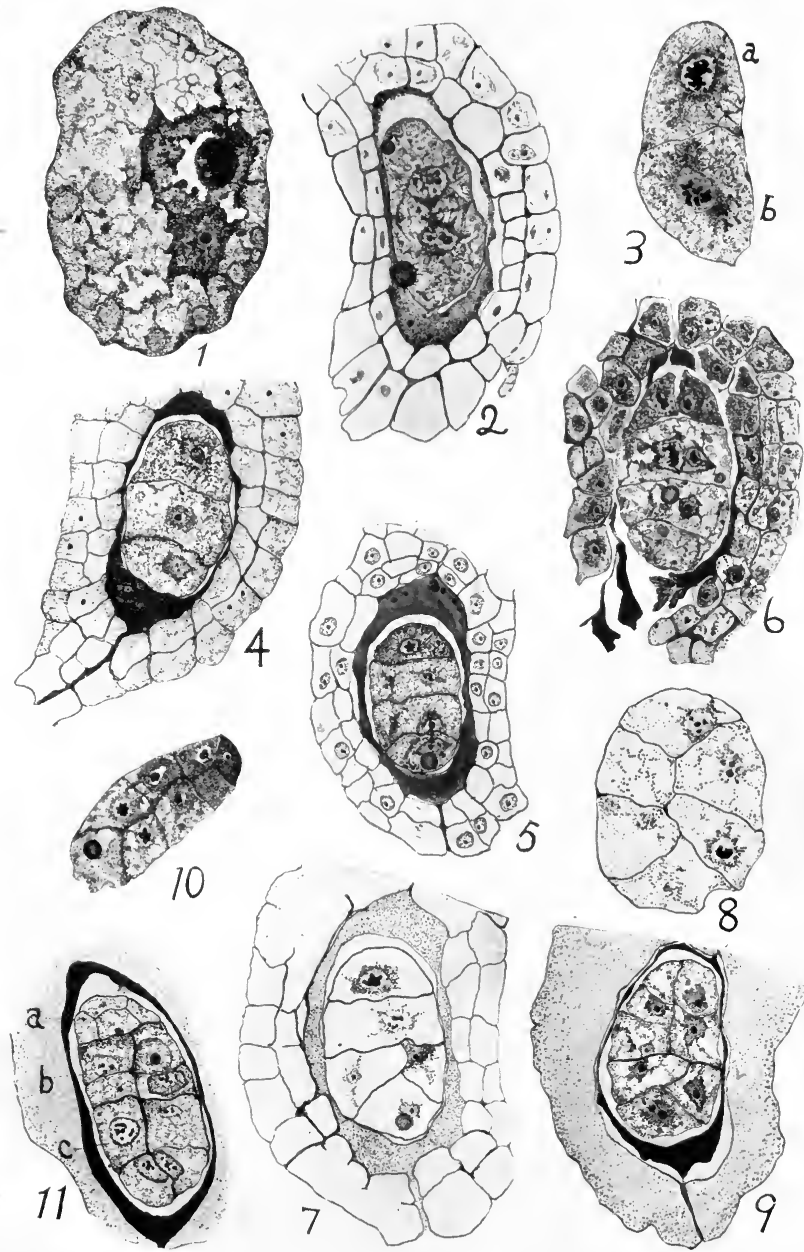

WOODBLRN: EMBRYOLOGY OF REBOLLIA 



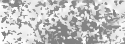

Whes

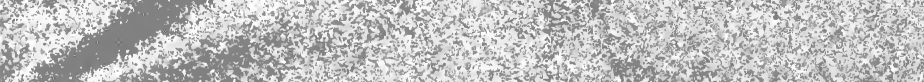

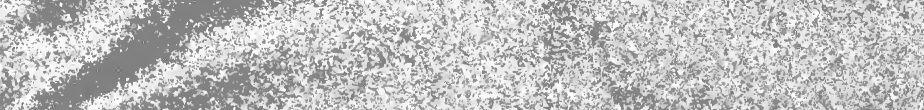

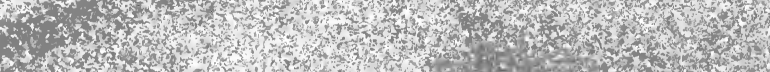
n.

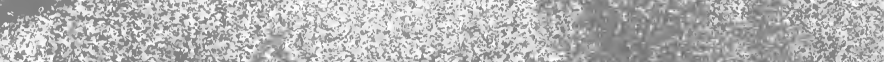

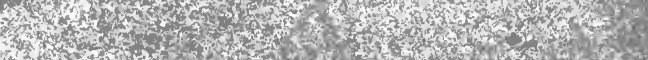

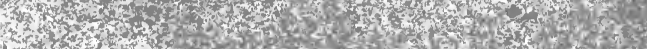

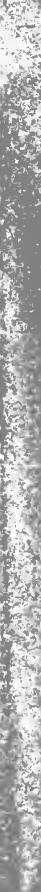

3.
w.

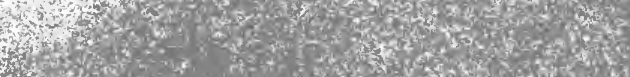
Wow

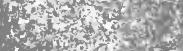

4. 30 ,

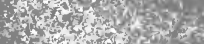

2.

Thon

$m$ in

intong

$x \rightarrow x+3$ as

P.t.

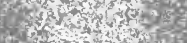

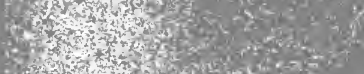

2.

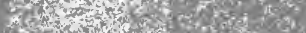

3.t.

int

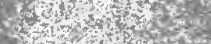

W. W. W

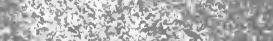

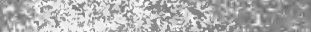

Ap.

s.t.

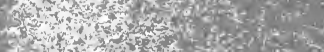

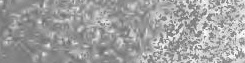

revito

2.

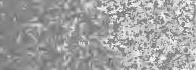

$7,-20$

(2)

2.

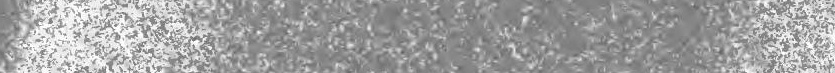

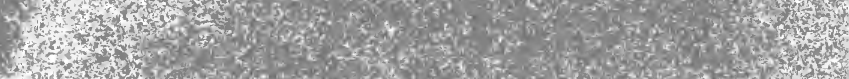

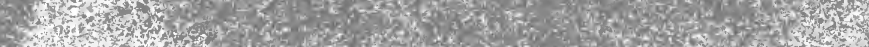
15.

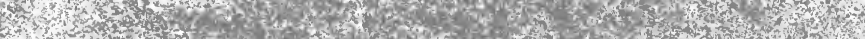
1.7.

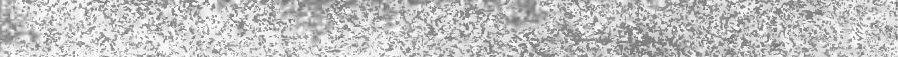
4.6. 30
3 3.

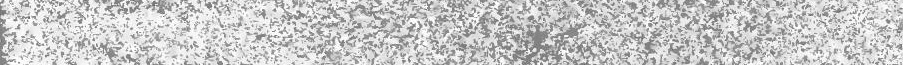

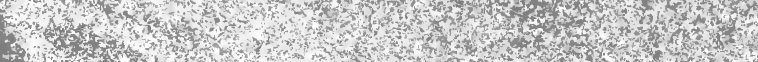




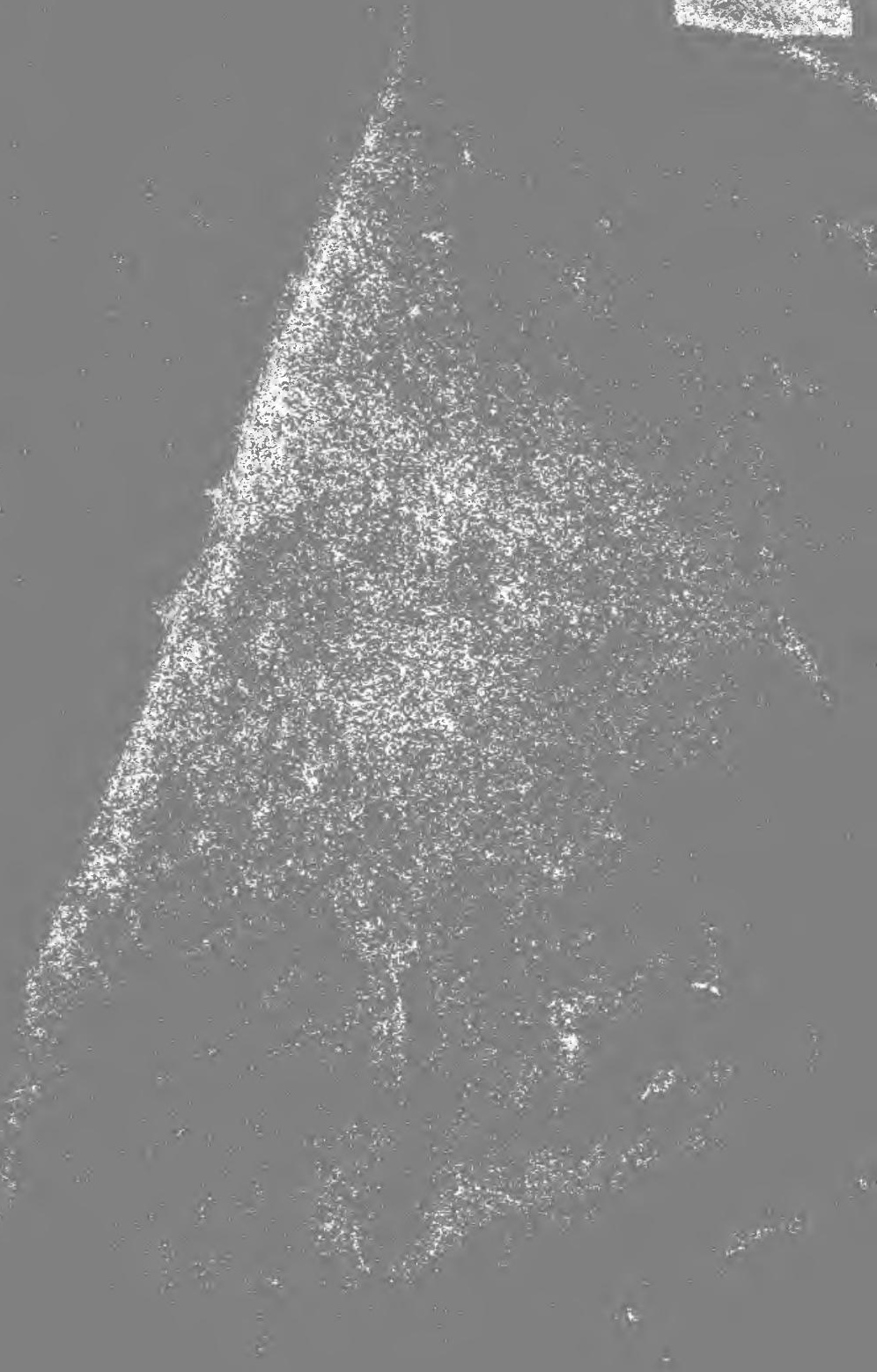




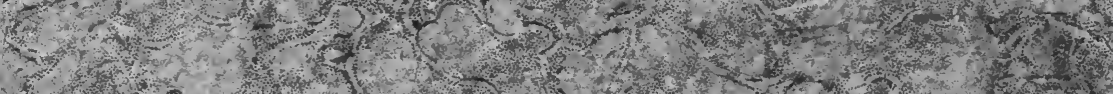

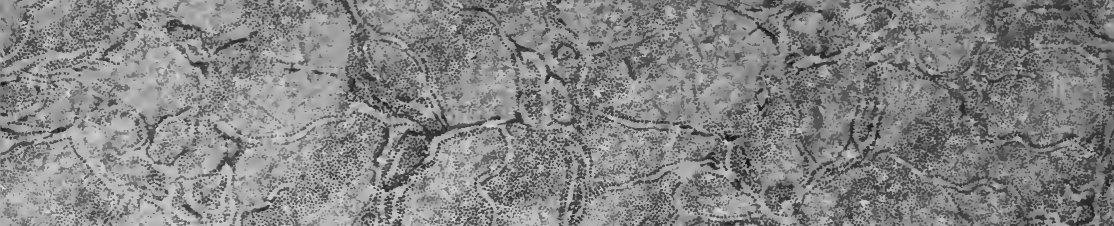

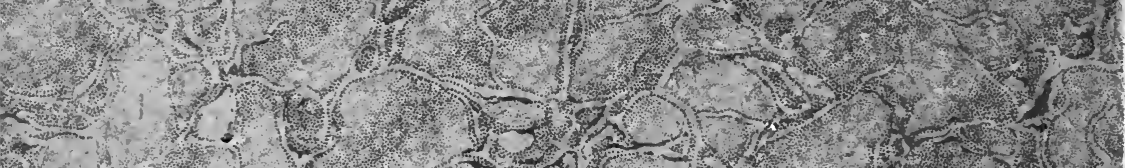
$20 .+2-33^{3}+2=$

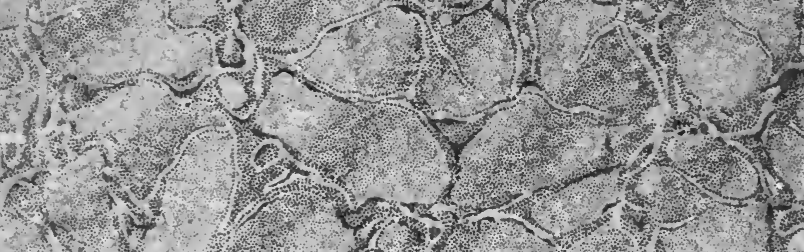

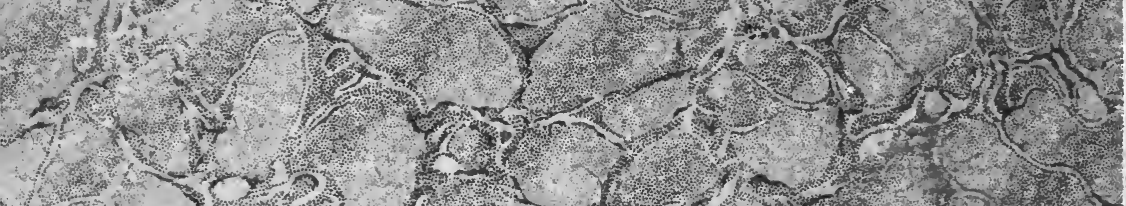
$x^{2}+3,-3=2$

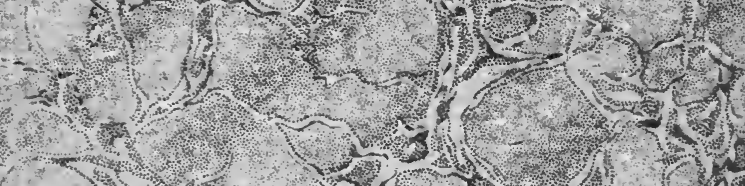

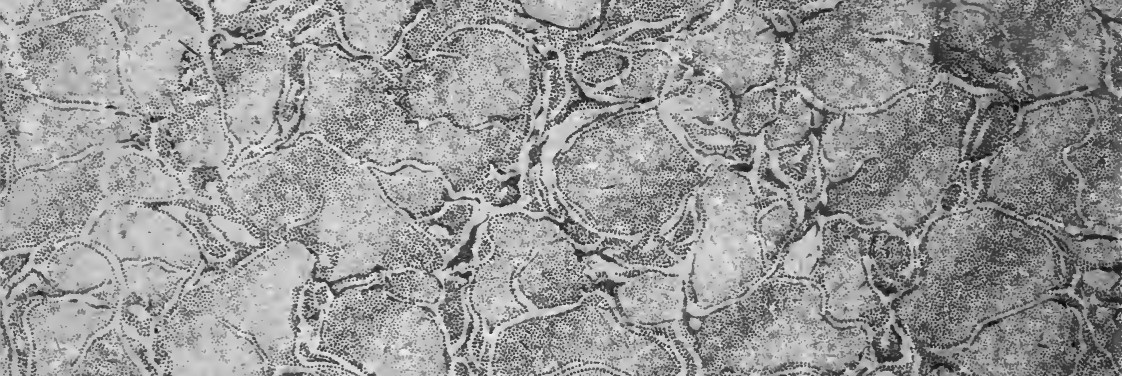

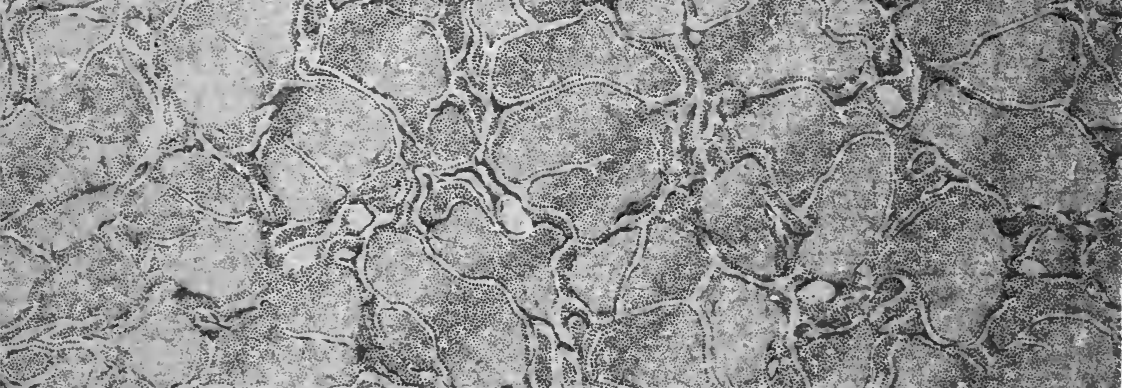

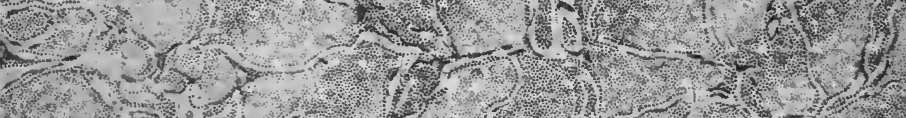

+
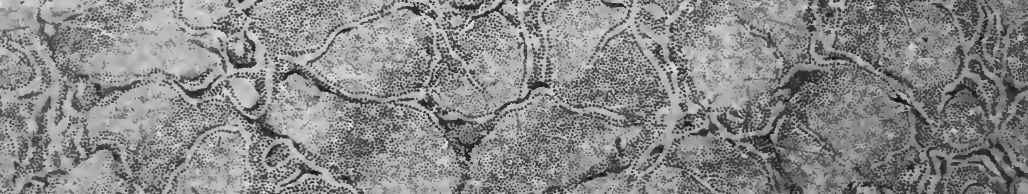